\title{
On Scalarity in the Verbal Domain. The Case of Polish Psych Verbs. Part 1: Polish Perfective Psych Verbs and Their Prefixes
}

\begin{abstract}
Polish perfective psych verbs are generally analyzed as inceptive predicates focusing the beginning of an emotional state holding of an experiencer. However, a perfective psych verb can also denote an event of gradual scalar change. In this paper, I argue that on the inceptive reading a perfective psych predicate denotes a transition from a state in which $p$ does not hold to a state in which $p$ holds of an experiencer. In events of gradual change, there is an increase in the degree on the scale of intensity of a given psych state or on the (abstract) extent scale contributed by a verb's argument. As the internal temporal structure of the events denoted by perfective psych predicates can depend on elements of syntactic context outside the verb, the domain of aspectual composition in Polish is not the verb, pace Rothstein (2020), but VoiceP/vP.
\end{abstract}

\section{Keywords}

inceptivity, Aktionsart, perfectivity, Scale Hypothesis, scalar change, degree achievement, experiencer, Polish

\section{Streszczenie}

Dokonane czasowniki stanów emocjonalnych analizowane są zwykle jako czasowniki wyróżniające fazę początkową danego stanu. Te same predykaty mogą $\mathrm{w}$ pewnych kontekstach składniowych wyrażać znaczenia ewolutywne. W artykule przedstawiona jest hipoteza, że w kontekstach inicjalnych, czasownik wyraża moment zaistnienia stanu w nosicielu. W kontekstach ewolutywnych, predykat wyraża stopniową zmianę na skali intensywności stanu lub stopniowe nabycie stanu przez wszystkie części podzielnego argumentu czasownika. Zależność interpretacji wewnętrznej struktury temporalnej zdarzeń opisywanych 
przez dokonane czasowniki stanów psychologicznych od kontekstu składniowego pokazuje, wbrew tezie w pracy Rothstein (2020), że interpretacja rodzaju zdarzenia ustalana jest $\mathrm{w}$ języku polskim na poziomie struktury zdaniowej (VoiceP/ $/ \mathrm{P})$.

\section{Słowa kluczowe}

inicjalność, Aktionsart, aspekt dokonany, Hipoteza Skali, zmiana skalarna, czasownik parametryczny, nosiciel stanu, język polski

\section{The problem*}

This paper focuses on the semantics of perfective Polish psych verbs, which are analyzed in the literature as predicates focusing the beginning of the psych state lexicalized in a given verb(al root) (Rozwadowska 2003, 2012, 2020; Młynarczyk 2004; Pastuchowa and Stawnicka 2008; Wiemer and Seržant 2017, inter alia). ${ }^{1}$ On this view, the temporal interval over which the state denoted by the perfective psych predicate holds of the experiencer (Exp) in (1b) includes an initial boundary, unlike in (1a), where the interval in which the state expressed with the imperfective verb holds does not have a specified onset. ${ }^{2,3}$

* This research is funded by grant 2014/15/B/HS2/00588 from National Science Centre, Poland.

${ }^{1}$ The term 'psych verb' is due to Levin (1993: 189), where a psych verb is taken to relate an emotional state to an individual, the holder or bearer of the state in Verhoeven's (2007) typology of experiential verbs. Apart from verbs of emotional state, Verhoeven classifies as experiential predicates also verbs of bodily sensation, cognition, volition and perception. Psych verbs are typically dyadic predicates with an experiencer (Exp) and a second argument, which has been variably referred to as theme (Belletti and Rizzi 1988), stimulus (Landau 2010; Grafmiller 2013), causer, target-of-emotion (T), or subject matter-of-emotion (SM) (Pesetsky 1995). The second argument of a psych verb will be referred to here as stimulus (S).

${ }^{2}$ The prefixes are bolded in the examples given in this paper and they are separated from their bases with a full stop mark in the glosses. The superscript $I$ on a verb indicates imperfective aspect and $P$ indicates perfective aspect, a notation used throughout this paper. Grammatical information is given in the glosses only where necessary. The abbreviations used in the glosses are as follows: $1 / 2 / 3-1^{\text {st }} / 2^{\text {nd }} / 3^{\text {rd }}$ person; ACC - accusative, AGR - agreement; F - feminine gender; GEN - genitive case; IMP - imperative; IMPERS - impersonal; INF - infinitive; INST - instrumental case; $\mathrm{M}$ - masculine gender; $\mathrm{N}$ - neuter gender; OBL - oblique; POss - possessive; PTCP - participle; SE - reflexive pronoun/Voice marker; SG - singular number; PL - plural number.

${ }^{3}$ The lexical semantics of the verbs discussed here has been consulted with Słownik języka polskiego (https://sjp.pl), abbreviated here as SJP, and Słownik języka polskiego PWN [PWN Dictionary of Polish] (https://sjp.pwn.pl/), henceforth referred to as SJP PWN. Where available, the translational equivalents of Polish verbs are from the PWN English-Polish Dictionary (https://dictionary.cambridge.org/pl/dictionary/english-polish/) and from the PWN Polish-English Dictionary (https://dictionary.cambridge.org/pl/dictionary/polish-english/). Naturally-occurring examples are from the National Corpus of Polish (NKJP) available at http://nkjp.pl/ (cf. Przepiórkowski et al. 2010), the SJP PWN Corpus abbreviated here as SJPC (http://korpus. pwn.pl/), from random Google searches, and/or from the research listed in the References. The examples without a specified source are constructed. 


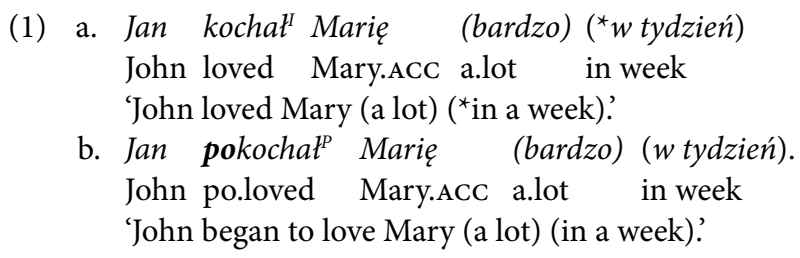

However, perfective psych verbs can also denote events of gradual change along a scalar dimension. In the situation described in (2), there is a gradual increase in the intensity of the psych state holding of Exp between the beginning and the end of the interval specified by the time span adverbial $w$ niecaly miesiąc 'in less than a month'.

(2) W niecaly miesiac Jan stopniowo pokochat ${ }^{P}$ Marię in not.whole month John gradually po.loved Mary.ACC jeszcze bardziej. even more 'John gradually got to love Mary even more in less than a month.'

In the naturally-occurring example in (3a), the perfective psych predicate expresses a change along the extent scale associated with Exp, which is decomposable into component countries and acquires the property of being in the given psych state part by part. That Exp serves as an incremental theme in (3a) is corroborated by the availability of the adverb stopniowo 'gradually', which tracks the part-structure of Exp, as shown in (3b).

(3) a. W ciagu dwóch dekad zachód

in duration two.gen decades.geN West.NOM

zniechęcit $P^{P}$ się do Pakistanu. (Google)

z.disheartened SE to Pakistan

'The West has become disheartened towards Pakistan over the course of (the last) two decades/Western countries have become disheartened towards Pakistan over the course of (the last) two decades.'

b. W ciagu dwóch dekad zachód stopniowo zniechęcip się do Pakistanu.

'The West has gradually become disheartened towards Pakistan over the course of (the last) two decades/Western countries have gradually become disheartened towards Pakistan over the course of (the last) two decades.'

Thus, when a perfective psych predicate is interpreted inceptively, as in (1b), there is no progress or advancement along the temporal scale and there is no increase along the intensity of a state or along the extent dimension. The time span adverbial in (1b) measures the time between some reference time and the time of the occurrence of the event, i.e. it has the after and not the during interpretation (cf. Beavers 2012, 2013). In contexts in which a perfective psych predicate denotes an event of gradual scalar change, as in (2) and (3), there is 
progress along, respectively, the scale of intensity and the scale of extent, which correlates with progress along the temporal scale. Here, the time span adverbials have the during, and not the after interpretation.

The main question that sentences like (1b), (2) and (3) raise is how the internal temporal structure of the events denoted by the perfective predicates, i.e. their Aktionsart, is determined in Polish and how the same morphological form of a verb can give rise to a punctual or a gradual change reading in context. In Slavic languages, in which the perfective/imperfective distinction is grammaticalized and almost every verb is either perfective or imperfective in all its forms, perfective verbs are often taken to denote delimited events with a final endpoint. Filip and Rothstein (2006), Filip (2008, 2017), and Rothstein (2020) argue that Slavic perfective verbs denoting events with a final endpoint lexicalize a null maximalization operator, defined in (4), which applies to (partially ordered) events and yields sets of maximal or telic singular events.

(4) Telicity corresponds to the maximalization operator $M A X_{E}$. It is a monadic operator, such that $\operatorname{MAX}_{E}(\Sigma) \subset \Sigma$, which maps sets of partially ordered events $\Sigma$ onto sets of maximal events $M A X_{E}(\Sigma)$. (Filip 2008: 219)

Importantly, an event can be maximal only with respect to some scale, where a scale is a device for measuring an event (in context). For $M A X_{E}$ to pick out the largest event, the scale must be bounded, i.e. it must have a final endpoint. As events cannot be directly measured (Krifka 1989), the scales are provided by arguments or by run times. For example, drink by itself denotes a set of unordered drinking events, which can be partially ordered relative to the volume of the object that is consumed in a drinking event, e.g. wine, which provides a criterion for ordering wine-drinking events according to the quantities of wine drunk in a set of events. An event of taking a sip of wine may develop into a larger, more developed event, e.g. an event of drinking a glass of wine, two glasses of wine, a bottle, etc. The maximal event is the most developed version of the set of (partially) ordered events. The objects that can measure events can also be abstract measuring scales, e.g. an hour indirectly measures the temporal trace of the event denoted by John walked for an hour. Depending on a language, $M A X_{E}$ can be overtly realized by a morphological marker, e.g. a prefix, suffix, or a complex predicate construction, etc., or it can be null (cf. Filip 2008, 2017). Furthermore, it can apply at different levels in the semantic representation of events. In English, $M A X_{E}$ is phonologically null and it applies to the denotation of VP (or IP). In Russian, and potentially in other Slavic languages, $M A X_{E}$ is null, like in English, but it is present in perfective underived and derived verb stems and not at the VP/IP-level. According to Filip $(2008,2017)$, perfective-stem forming prefixes (and the semelfactive suffix - $n u$ in Russian) are not markers of perfectivity (cf. also Filip \& Rothstein 2006; Rothstein 2020). The main reason why the prefixes in perfective verbs 
are not overt exponents of $M A X_{E}$ is that prefixes are present in the perfective stems of both maximal and non-maximal events, as illustrated with the Polish examples in (5a) and (5b) respectively. In addition, they are part of the morphological structure of secondary imperfectives, as illustrated in (5c) and (5d). If prefixes encoded perfectivity, the secondary imperfectives in (5c) and (5d) would be marked both for perfectivity and for imperfectivity, which have incompatible formal and semantic properties.

(5) a. wyjechać ' 'leave'

b. wytrzymaćp 'bear, endure'

c. wyjeżḋaćl 'leave/be leaving'

d. wytrzymywaćl 'bear/be bearing, endure/ be enduring'

Rothstein (2020) argues that there are three ways in which a maximal event can be born in a language in which the perfective is a $\mathrm{V}$ operator, such as Russian (and potentially other Slavic languages). First, the final endpoint can be contributed by an underived verb itself. Underived achievements, which denote transitions "from a situation or state of not being in a certain place to a state of being in that place" (Rothstein 2020: 166) are examples of verbs which lexically encode an endpoint. Rothstein includes in the class of underived Russian achievements verbs of appearance like javit's $a^{P}$ 'appear', verbs of change of possession like dat ${ }^{\text {PP }}$ 'give' and verbs of change of position like sest ${ }^{\text {P }}$ 'sit down'. Second, a verb can be derived with a so-called pure perfectivizing prefix, which does not change the lexical meaning of the base (imperfective) verb or root and adds the meaning of completion. Verbs with pure perfectivizing prefixes have secondary imperfective partners. According to Rothstein, a prefix in a perfective verb with a secondary imperfective partner indicates that the parameter for maximalization is the incremental structure of the event denoted by the verb. A third category of perfective verbs are verbs without a secondary imperfective partner, in which the prefix adds lexical information that determines the scale along which the events in the denotation of a perfective predicate are ordered. The scale can be spatial, temporal, etc. The temporal scale is lexicalized, e.g., in the delimitative prefix po-, which derives temporally delimited activity verbs, as illustrated with the Polish example in (6).

(6) Jan pospacerowat ${ }^{P}$ wczoraj godzinę.

John po.walked yesterday hour.ACC

'John walked for an hour yesterday/John spent an hour walking yesterday'.

According to Filip (2008), Filip and Rothstein (2006), and Rothstein (2020), the events denoted by a verb derived with the delimitative prefix po- are maximal and telic. As the prefixed verb itself provides the endpoint, which corresponds to a vague measure of 'a short while', the durative adverbial in (6) does not endow the denoted events with a final endpoint. Instead, it simply 
provides further information as to what counts as 'a short while' in a given context (but cf. Piñon 2001 for the view that the verbal predicate in (6) is atelic and that it is telicized by the adverbial).

Perfective psych verbs in (1b), (2) and (3) raise two main problems for the account outlined above. First, if the psych verb in (1b) is a derived achievement predicate, which is how Filip (2008) analyzes Czech counterparts of cognitive experiential verbs like recognize and notice, it is interpreted by means of $M A X_{E}$. Cognitive verbs like recognize are analyzed as achievements, among others, in van Voorst (1992) and Rothstein (2004) in reference to English, Rothmayr (2009) in reference to German, and Młynarczyk (2004) and Łazorczyk (2010) in reference to Polish. Following Vendler (1967), achievement predicates are analyzed as punctual, i.e. as true of a single time moment (Smith 1997; Filip 2008, inter alia). ${ }^{4}$ The evidence in support of the punctual character of achievements is that they are compatible with a time span adverbial with an after reading, as in (1b), and with time-point adverbials like suddenly (Smith 1997: 49). As shown in (7), Polish perfective psych predicates are compatible with nagle 'suddenly'.
(7) Obóz władzy pokochat ${ }^{P}$ nagle Olge Tokarczuk. (Google) camp establishment po.loved suddenly Olga.ACC Tokarczuk.ACC 'The ruling establishment suddenly began loving Olga Tokarczuk.'

As Filip (2008) notes herself, analyzing achievements as punctual is problematic for the assumption that they are interpreted by means of $M A X_{E}$, as being punctual, they do not have parts that could be stages of one another. Filip nonetheless takes $M A X_{E}$ to apply to achievements, albeit by default.

The second problem that Polish perfective psych verbs pose for the view that $M A X_{E}$ is V-internal is that although neither the root verb nor the prefix changes in (2) and (3), the maximality of the events in (2) and (3) is determined with respect to different scales. In (2), the final endpoint of the event of change is provided by the final degree to which the intensity of the state changes in the interval over which the state holds of Exp in the denoted event. This final degree is the target degree in the structure of a comparative adverb (cf. Kennedy and McNally 2005). In (3), maximality is determined with respect to the upper-bounded extent scale associated with the experiencer argument, which denotes a plurality of countries and can thus serve to determine a maximally developed stage of an event of change. The examples in (2) and (3) thus show that the domain of aspectual composition is not V, similarly to a language like English, in which the internal temporal structure of events is typically determined at the level of VP, but can also be determined at the level

\footnotetext{
${ }^{4}$ However, achievements are analyzed as occupying two adjacent moments on the temporal axis in Rothstein (2004), Rappaport Hovav (2008, 2014), and Beavers (2012, 2013). See also fn. 6.
} 
of VoiceP $/ v \mathrm{P}$. The latter is shown in (8), where the incremental structure of the denoted events and their final endpoints are determined by the subject arguments (Rothstein 2004; Filip 2008; Beavers 2012, 2013).

(8) a. John entered the icy water (very slowly).

b. At the turtle race, the winning turtle crossed the finish line in 42 seconds.

To account for the different readings of perfective psych predicates in context, viz. the inceptive reading in (1b) and the gradual scalar change readings in (2) and (3), I argue here that a perfective psych verb describes a transition along a scale in all its uses. Interpreted inceptively, a perfective psych verb denotes an event of punctual scalar change, i.e. a transition from a situation in which a given (psych) state does not hold to a situation in which it holds (cf. Rappaport Hovav 2008, 2014; Beavers 2012, 2013). Although an inceptively interpreted perfective psych verb is a punctual event, it does not culminate any preliminary process leading up to the transition (cf. Rozwadowska 2012, 2020), similarly to recognize and notice in English. However, as the event has exactly two parts, which can be ordered with respect to each other on a twopoint scale $[0,1]$, the denoted events can be interpreted by means of $M A X_{E}{ }^{5,6}$ On a gradual change reading, a perfective psych predicate has more than two parts and it is associated with a multi-point property (intensity) scale with a final degree contributed by a comparative adverbial or by a bounded argument of the verb the part-structure of which determines the extent of change. Assuming that a comparative adverbial is an adjunct to VoiceP/ $/ v \mathrm{P}$ in (2) and that the (experiencer) argument that provides the extent scale is in the specifier of Voice $\mathrm{P} / v \mathrm{P}$ in (3), the aspectual interpretation of a perfective psych predicate is not determined (solely) at the level of $\mathrm{V}$ in Slavic, contra Rothstein (2020), but at the level of VoiceP/ $/ v$.

The remainder of this paper is structured as follows. In Section 2, I investigate the prefixes forming the stems of perfective psych verbs interpreted inceptively with a view to determining if their distribution is sensitive to the argument realization class of a given psych verb, as determined by the morphosyntactic properties of the verb's argument(s) (cf. Dahl and Fedriani 2012). This section is also concerned with finding out whether a prefix can change the core meaning of the base verb or root, whether perfective and imperfective

${ }^{5}$ According to Beavers (2013: 691), a minimal event of change takes two time moments. The zero-point on a two-point scale is the beginning and the final point (1) is the end of a minimal event of change. While punctual events of scalar change have exactly two parts in their lexical meaning, I assume here that they are true at a single time moment, which is the onset of a given psych state (cf. also Rozwadowska 2012, 2020). The beginning of the given psych state is the maximal stage in the denotation of a perfective psych verb interpreted inceptively.

${ }^{6}$ Note that a perfective psych verb can also denote a transition out of a psych state, e.g. odkochać $c^{p}$ się 'to stop loving.' 
psych verbs with the same core (lexical) meaning have different c-selectional and case-licensing properties, and whether the combination of a prefix and a verbal base or root can give rise to an idiosyncratic meaning. If the prefixes forming perfective psych verbs are not argument structure modifiers, they do not have secondary imperfectives and their contribution to the base or root is fully compositional, they qualify as superlexical and can be analyzed as markers of perfectivity with scope over VoiceP/ $v$ P (Ramchand 2004, 2007; cf. also Svenonius 2004; Gehrke 2008, inter alia). In this section, I show that although the prefixes in perfective psych verbs are not argument structure modifiers, a number of perfective psych verbs have secondary imperfective partners and thus they are VP-internal, and further, the combination of the prefix and the base verb or root is not always (fully) compositional. Thus, I will not analyze the prefixes in perfective verbs with a psych-state denoting base verb or root as superlexical here (cf. also Žaucer 2005 in reference to inceptive $z a$-in Slovenian, Wiland 2012 in reference to Polish $z a$-, and Tatevosov 2015 in reference Russian $z a$-). Instead, following, among others, Filip $(2008,2017)$, the prefixes in the perfective (psych) verbs will be taken here to encode scale as well as event endpoints.

In Section 3, I investigate the event structure of perfective psych verbs interpreted inceptively (cf. (1b)). I show here that eventive (prefixed) imperfective psych verbs that allow the progressive induce the imperfective paradox, a property they share with simplex events of change analyzed as happenings in Bach (1986), but not with Bach's culminations. Building on Rappaport Hovav $(2008,2014)$ and Beavers $(2012,2013)$, I argue here that similarly to happenings, perfective psych predicates interpreted inceptively are punctual events with exactly two parts ordered on a two-point $[0,1]$ scale. I further suggest that the scale is projected by a prefix deriving a perfective psych verb. A punctual perfective psych verb is a simplex event in the sense of Beavers (2012, 2013 ), i.e. it is a transition from a state in which $p$ does not hold to a state in which $p$ holds (of the experiencer). The happenings denoted by perfective psych verbs can be interpreted by means of $M A X_{E}$ not by default, contra Filip (2008), but because they have exactly two atomic parts (Beavers 2013: 691). The final endpoint on the two-point $[0,1]$ scale is the beginning of the psych state lexicalized in the base verb or root (cf. fn. 6). Thus, the events denoted by perfective psych verbs are acceptable with time span adverbials only on an after reading (Rozwadowska 2012, 2020). To account for the stative perfect readings of punctual psych verbs, on which a psych state that begins in the past holds at utterance time, following Ramchand $(2004,2007)$, the perfective and imperfective will be assumed here to be null operators of viewpoint aspect in the head of AspP. An operator of grammatical (viewpoint) aspect relates a reference time variable $(t)$ to a single time moment in the temporal trace of an event $(\tau)$ (Ramchand 2004: 333). However, as a perfective verb can 
have the temporal trace of an event $(\tau)$ as an argument, as argued, among others, by Filip (2008, 2017), Kagan (2015), Rothstein (2020), following Gehrke and Grillo (2009), event time $(\tau)$ and its relation to the reference time variable $(t)$ will be taken to be represented at the level of VoiceP $/ v \mathrm{P}$, and not at the level of AspP.

In Section 4, I offer an informal analysis of Polish perfective psych predicates denoting complex events in the sense of Beavers (2012, 2013), i.e. events of change with more than two parts, the initial and the final, which are associated with a multivalued scale and which can thus be modified by time span adverbials with a during reading. The complex events of change denoted by perfective psych predicates are the events of gradual scalar change in (2) and (3), in which the scale of change is contributed by linguistic context and not by the prefix. Agentively interpreted perfective psych verbs, which are derived accomplishments, are also complex events of change. They have an incremental event structure with an unspecified process event leading up to a result state. The endpoint on the multi-point scale of change is the beginning of a (result) psych state. ${ }^{7}$ The interpretive options available to perfective psych predicates in different linguistic contexts in Polish support scalar approaches to verb meaning (cf. Rappaport Hovav 2008, 2014 and the references therein) and to the meaning of verbal prefixes in Slavic offered in Filip (2003, 2008, 2017), in which verbal prefixes deriving perfective verbs introduce an ordering on event stages which can be along a different scale in context (cf. also Kagan 2015). The same morphological form of a perfective psych verb can give rise to a punctual or a gradual change reading because the denoted events are events of scalar change, which include in their semantic representation a transition point to a (result) psych state holding of Exp. Section 5 concludes the paper.

\footnotetext{
${ }^{7}$ Not all (im)perfective verbs with Exp mapped onto an internal argument have an agentive reading and not all imperfective verbs have an eventive reading. The agentive reading, illustrated in (i), licenses an agent-oriented adverb celowo 'deliberately' and describes an event of change of state The eventive reading, in which the subject argument does not act with the purpose of triggering a given psych state in Exp, but Exp undergoes a change of state is shown in (ii). Here, the subject argument is a non-agentive stimulus. The stative reading is illustrated in (iii). In Biały (2005), the criteria distinguishing between stative and eventive/agentive psych verbs with Exp mapped onto an internal argument in Polish include compatibility with time-point adverbials, imperative mood, bound iterativity, and distinct interpretations in present tense.
}

(i) Jan (celowo) rozzłościt $P^{P}$ Marię. John deliberately roz.annoyed Mary.ACc 'John deliberately annoyed Mary.'

(ii) Jan rozzłościt ${ }^{P}$ Marię swoim zachowaniem. John roz.annoyed Mary.ACC SE.POss.INST behavior.INST 'John annoyed Mary with his behavior.'

(iii) Zachowanie Jana złościło ${ }^{I}$ Marię (cały wieczór). behavior John.GeN annoyed Mary.Acc entire evening 'John's behavior annoyed Mary (the whole evening).' 


\section{Argument structure and argument realization classes of Polish psych verbs and their prefixes}

This section investigates the distribution of prefixes in perfective psych verbs in Polish. The psych verbs are divided here into argument realization classes based on the morphosyntactic properties of the experiencer (Exp) and stimulus ( $S$ ) arguments to see if the distribution of prefixes is sensitive to the argument realization class to which a predicate belongs. Dahl and Fedriani’s (2012) taxonomy of argument realization classes has been adopted here, as it can help identify language-specific classes of psych verbs and verb(al root)s that can belong to more than one argument realization class in a language. As in Dahl and Fedriani (2012), only NPs or PPs realizing the Exp and/or S argument are taken into account here. Some of the classes are further divided into subclasses depending on whether only the perfective verb is prefixed or both a perfective and an imperfective verb with the same lexical meaning have prefixed stems. ${ }^{8}$ The presentation and discussion of the argument structure and argument realization classes of Polish psych verbs is preceded by a short note on the morphological structure of a Polish verb.

\subsection{Polish verbal morphology}

Polish has robust verbal morphology (Laskowski 1999; Wróbel 1999; Młynarczyk 2004; Łazorczyk 2010; Szymanek 2010, inter alia) and verbs have complex morphological structure, which Czaykowska-Higgins (1998) decomposes into four stems: the C-stem, the VS-stem, the TM stem, and the $\mathrm{P} / \mathrm{N}$-stem. The C-stem is an underived root or a stem derived with a prefix, VS is the stem formed with a verbalizing suffix, TM is the stem to which tense/ infinitive/participle morpheme attaches, and $\mathrm{P} / \mathrm{N}$ is the stem to which agreement (person, number and gender in the past tense) morphology attaches, as shown in (9).

(9) $\left[\left[_{\mathrm{TM}}\left[{ }_{\mathrm{VS}}\left[{ }_{\mathrm{V}}\left(\right.\right.\right.\right.\right.$ Prefix) $\left.\left.\left.\left.[\text { C-stem }]_{\mathrm{V}}\right](\mathrm{VS})_{\mathrm{V}}\right](\mathrm{TM})_{\mathrm{TM}}\right] \mathrm{P} / \mathrm{N}\right]$

Perfectivity is usually morphologically marked by means of a prefix or a suffix in Polish, as shown in (10).

(10) a. kochaćt / pokochaćp 'love'

b. blyskać / blysnąic 'flash'

\footnotetext{
${ }^{8}$ This section draws on the work on Polish psych verbs in Biały (2005), Bondaruk and Szymanek (2007), Rozwadowska (2003, 2012, 2020), Rozwadowska and Bondaruk (2019), and Bondaruk (2020).
} 
Primary imperfective verbs are not prefixed. Secondary imperfectives are prefixed and they are formed with the suffix $-y w a$ and its allomorphs (cf. Laskowski 1999; Szymanek 2010). The verbalizing suffix $-a$ in the stem of the imperfective verb in (11b), which alternates with the verbalizing suffix $-i$ in the perfective verb, is a secondary imperfective (SI) suffix. Both the prefixes and the suffixes are bolded in (11b).

(11) a. podpisaćp / podpisywaćl 'sign'

b. zniechęcíc ${ }^{P} /$ zniechęcaćl 'dishearthen'

Polish perfective verbs are systematically distinguished from imperfective verbs by their behavior with respect to the tense system. Unlike imperfective verbs, perfective verbs cannot occur with the future tense auxiliary, they cannot form present tense participles, their non-past tense forms have future time reference, and the verbs cannot occur as complements of phasal verbs, e.g. skończyć 'stop'. A vast majority of verbs are perfective or imperfective in Polish. The verbs that behave with respect to the tense-related criteria like perfectiveandlike imperfective verbs without any change in their morphological form are biaspectual verbs. ${ }^{9}$

The list of the Polish verbal prefixes in (12) is given after (Wróbel 1999: 539)..$^{10,11}$

(12) Polish verbal prefixes

de-; do-; na-; nad(e)-; o/o(be)-; od(e)-; po-; pod(e)-; prze-; przy-, re-; roz(e)-; u-; w(e) $z$-/we(s)-; wspót-; wy-; $z(e) / s-/ s-; z a-$.

A well-known characteristic feature of prefixation in the verbal domain in Slavic, Polish including, is that a single prefix can combine with different base verbs/ roots. Conversely, different prefixes can combine with a single base verb/root. The ability of a verb(al root) to combine with different prefixes is shown in (13). ${ }^{12}$
myślećl 'think'
a. domyślićp się/ domyślaćl się 'guess'

${ }^{9}$ Among the 30, 860 imperfective and/or perfective verbs listed in Stownik gramatyczny języka polskiego (http://sgjp.pl), the largest database available for the study of verbal aspectual forms in Polish, there are only 179 biaspectual verbs. $35 \%$ of the total of the verbs in the database are aspect-invariable. The rest, ca. 65\%, are aspectually paired (Łaziński 2020: 44-45).

${ }^{10}$ The prefixes $o b(e)$-; prze-; roz(e)-; wy- and $w(e) z-/ w e(s)$ - do not have cognate prepositions in contemporary Polish.

${ }^{11}$ The list in (12) contains 19 prefixes, but the number of verbal prefixes differs in the literature (Łaziński 2020). The prefix wspót- 'co-' listed in Wróbel (1999: 539) does not distribute in perfective stems. It is likely not a prefix, but a bound root, as it is found in the adjective wspólny 'common' and the noun wspólnota 'community' (cf. also Łazorczyk 2010). The prefixes de- and re- are Latin borrowings.

${ }^{12}$ The cognitive verb myśleć 'to think' has been chosen to minimize the contrast with the class of psych verbs focused on here. Notice that sometimes the presence of a prefix correlates with the presence of the reflexive się 'SE'. 
b. namyślićp się/ namyślaćl się 'make up one's mind'

c. obmyślićp / obmyślaćl 'contemplate'

d. pomyśleć ${ }^{\prime}$ 'ponder, believe'

e. przemyśleć ${ }^{P}$ / przemyśliwać ' 'think through, rethink'

f. rozmyślać ' 'meditate, ponder'

g. rozmyślićp się/ rozmyślaćl się 'change one's mind'

h. umyślić ${ }^{P}$ / umyśliwać 'decide, plan'

i. wymyślićp / wymyślać 'invent, think up'

j. zmyślić $c^{P}$ zmyślaćl 'make up'

k. zamyślićp się/zamyślaćl się 'be lost in thought, be engrossed'

According to SGJP (Saloni et al. 2015) and to Łaziński (2020:300), the prefix poin (13d) is a pure perfectivizer. The only meaning it contributes to the lexical meaning of the base verb myślećl 'think' is the meaning of terminativity. However, it could also be analyzed as the delimitative po-, depending on syntactic context, as unlike Russian and Czech, the Polish delimitative po- does not necessarily imply that the temporal extent of an event fall short of some conventional expectation value (cf. Willim 2006). Furthermore, pomyślećp 'ponder, believe' can be modified by a durative adverbial except when the verb denotes a mental (epistemic) attitude. The other prefixes forming the perfective stems of verbs derived from the root $\sqrt{ }$ myśl- add idiosyncratic meaning and derive distinct verbs with a new meaning, argument structure, c-selectional restrictions and/or case-licensing properties. As the prefixes are argument structure modifiers, they are lexical prefixes in the classification of Slavic verbal prefixes in Svenonius (2004). For example, while the activity-denoting myślećl 'think' is not syntactically transitive and does not take a nominal complement/direct object, as shown in (14a) and (15a), obmyślićp /obmyślaćl (cf. (13c)) and wymyślićp ${ }^{p}$ wymyślać ${ }^{I}$ (cf. 13i)) are syntactically transitive and take a direct object in the accusative case (cf. (14b) and (15b) respectively).

(14) a. ${ }^{*}$ myślećl zemste think.INF revenge.ACC

Intended: 'devise/work out revenge'

b. obmyślicic/ obmyślaćl zemstę ob.think-INF ob.think.INF revenge.ACC 'devise/work out revenge'

(15) a. * myślećl nowa potrawe think.INF new dish.ACC Intended: 'devise a new dish'

b. wymyślicí ${ }^{\text {I }}$ wymyślaćl nowa potrawe wy.think.INF wy.think.INF new dish.ACC 'devise a new dish' 
Compared with other verbs, the perfective stems of Polish psych verbs are typically formed with a unique prefix (Młynarczyk 2004). This will be shown in the next section.

\subsection{The argument structure and argument realization classes of Polish psych verbs and their prefixes}

Based on the morphosyntactic properties of Exp and S arguments, Polish psych verbs can be divided into six argument structure and argument realization classes. ${ }^{13}$ The classes are presented and illustrated with selected examples in (16)-(21) below. ${ }^{14}$ Perfective verbs with secondary imperfective (SI) partners are listed separately from the verbs derived from the base verb/root via prefixation. A discussion of the distribution of the prefixes across the classes given below will follow the examples.

(16) $\operatorname{Exp}_{\mathrm{NOM}}-\mathrm{S}_{\mathrm{ACC}}$ (Exp in nominative case, $\mathrm{S}$ in (structural) accusative case)

$\begin{array}{lll}\text { imperfective } & \text { perfective } & \text { English equivalent } \\ \text { czuć } & \text { poczuć } & \text { 'feel' } \\ \text { kochać } & \text { pokochać } & \text { 'love' } \\ \text { lubić } & \text { polubić } & \text { 'like' } \\ \text { miłować } & \text { umiłować } & \text { 'love' } \\ \text { nienawidzić } & \text { znienawidzić } & \text { 'hate' } \\ \text { podziwiać } & \text { N/A } & \text { 'admire' }\end{array}$

(17) $\operatorname{Exp}_{\mathrm{NOM}}-\mathrm{S}_{\mathrm{OBL}}$ (Exp in nominative case, $\mathrm{S}$ in inherent/lexical case or PP)

$\begin{array}{lll}\text { imperfective } & \text { perfective } & \text { English equir } \\ \text { bać się } & \text { N/A } & \text { 'fear' } \\ \text { lękać się } & \text { zlęknać/zlec się } & \text { 'be afraid' } \\ \text { litować się } & \text { zlitować się } & \text { 'pity' } \\ & \text { ulitować się } & \text { 'pity' } \\ \text { obawiać się } & \text { N/A } & \text { 'fear' } \\ \text { tęsknić } & \text { zatęsknić } & \text { 'miss' }\end{array}$

(18) $\operatorname{Exp}_{\mathrm{NOM}}-\mathrm{S}_{\mathrm{OBL}}$ (Exp in nominative, obligatory reflexive clitic się, $\mathrm{S}$ in instrumental case or PP)

Class A: bare imperfective verb, prefixed perfective verb

$\begin{array}{lll}\text { imperfective } & \text { perfective } & \text { English equivalent } \\ \text { cieszyćsię } & \text { ucieszyć się } & \text { 'be pleased' } \\ \text { denerwować się } & z \text { denerwować się } & \text { 'be annoyed' } \\ \text { dziwić się } & \text { zdziwić się } & \text { 'be surprised' } \\ \text { ekscytować się } & \text { podekscytować się } & \text { 'be excited' } \\ \text { emocjonować się } & \text { rozemocjonować się } & \text { 'be excited' }\end{array}$

${ }^{13}$ The classes in (19) and (20) are the 'inverted constructions', in which S is not an external, but an internal argument, which is externalized in the syntax (cf. Dahl and Fedriani 2012).

${ }^{14}$ The list is not exhaustive and no quantitative analysis of the data will be offered here. 


\begin{tabular}{|c|c|c|}
\hline fascynować się & zafascynować się & 'be fascinated' \\
\hline frustrować się & sfrustrować się & 'be frustrated' \\
\hline gnębić się & zgnębić się $e^{15}$ & 'be worried' \\
\hline gniewać się & $\begin{array}{l}\text { pogniewać się } \\
\text { rozgniewać się }\end{array}$ & $\begin{array}{l}\text { 'be angry' } \\
\text { 'be angry, enraged' }\end{array}$ \\
\hline interesować się & zainteresować się & 'be interested' \\
\hline irytować się & zirytować się & 'be irritated' \\
\hline kochać się & zakochać się & 'be in love' \\
\hline martwić się & zmartwić się & 'worry' \\
\hline niepokoić się & zaniepokoić się & 'be anxious, worry' \\
\hline nudzić się & znudzić się & 'be bored' \\
\hline smucić się & zasmucić się & 'be sad, sadden' \\
\hline trapić się & strapić się & 'be worried' \\
\hline troskać się & zatroskać się & 'be worried' \\
\hline
\end{tabular}

Class B: prefixed perfective verb, prefixed imperfective verb (SI)

$\begin{array}{lll}\text { perfective } & \text { imperfective } & \text { English equivalent } \\ \text { obrazić się } & \begin{array}{l}\text { obrażaćsię } \\ \text { podkochiwać się }\end{array} & \text { 'be offended' } \\ \text { N/A } & \text { 'fancy, be besotted' } \\ \text { przejaćs się } & \text { przejmować się } & \text { 'be distressed' } \\ \text { przestraszyć się } & \text { przestraszać się } & \text { 'be frightened' } \\ \text { rozczulić się } & \text { rozczulać się } & \text { 'be touched' } \\ \text { rozkochać się } & \text { rozkochiwać się } & \text { 'fall passionately in love' } \\ \text { rozrzewnić się } & \text { rozrzewniać się } & \text { 'be moved' } \\ \text { rozweselić się } & \text { rozweselać się } & \text { 'be cheerful } \\ \text { rozwścieczyć się } & \text { rozwścieczać się } & \text { 'be infuriated' } \\ \text { wściec się } & \text { wściekać się } & \text { 'be mad' } \\ \text { zachwycić się } & \boldsymbol{z a c h w y c a c ́ ~ s i e ̨ ~} & \text { 'be delighted' } \\ \text { zadowolić się } & \boldsymbol{z a d o w a l a c ́ ~ s i e ̨ ~} & \text { 'be content' } \\ \text { zadziwić się } & \boldsymbol{z a d z i w i a c ́ ~ s i e ̨ ~} & \text { 'marvel' } \\ \text { zakochać się } & \boldsymbol{z a k o c h i w a c ́ ~ s i e ̨ ~} & \text { 'fall in love' } \\ \text { zawstydzić się } & \boldsymbol{z a} \text { astydzać się } & \text { 'be ashamed' } \\ \text { zdumieć się } & \boldsymbol{z d u m i e w a c ́ ~ s i e ̨ ~} & \text { 'be amazed' } \\ \text { zniechęcić się } & \boldsymbol{z} \text { niechęcać się } & \text { 'be disheartened' }\end{array}$

(19) $\operatorname{Exp}_{\mathrm{ACC}}-\mathrm{S}_{\mathrm{NOM}}$ (Exp in (structural) accusative case, $\mathrm{S}$ in nominative case)

Class A: bare imperfective verb, prefixed perfective verb

$\begin{array}{lll}\text { imperfective } & \text { perfective } & \text { English equivalent } \\ \text { bawić } & \text { rozbawić } & \text { 'amuse' }\end{array}$

${ }^{15}$ The perfective $z$ gnębić ${ }^{P}$ sie 'be worried' is not listed in SJP PWN or in PWN Oxford Polish-English Dictionary and Cambridge Polish-English Dictionary. A naturally-occurring example of zgnębić $c^{P}$ się from a Google search is given in (i).

(i) Dziadek [...] zgnębit ${ }^{p}$ się tym. (Google) grandfather z.worried SE this.INST 'Grandfather got worried about this.'

${ }^{16}$ Roz- in verbs like rozgniewać $^{P}\left(\right.$ się), rozkochać $c^{P}$ (się)/rozkochiwaćl (się), etc. is an intensifying prefix. 


$\begin{array}{lll}\text { ciekawić } & \text { zaciekawić } & \text { 'interest' } \\ \text { czarować } & \text { oczarować } & \text { 'charm' } \\ \text { denerwować } & \text { zdenerwować } & \text { 'annoy' } \\ \text { drażnić } & \text { rozdrażnić } & \text { 'annoy' } \\ \text { dziwić } & \text { zdziwić } & \text { 'surprise' } \\ \text { ekscytować } & \text { podekscytować } & \text { 'excite' } \\ \text { interesować } & \text { zainteresować } & \text { 'interest' } \\ \text { irytować } & \text { zirytować } & \text { 'irritate' } \\ \text { fascynować } & \text { zafascynować } & \text { 'fascinate' } \\ \text { frustrować } & \text { sfrustrować } & \text { 'frustrate' } \\ \text { gnębić } & \text { zgnębić } & \text { 'depress, trouble' } \\ & \text { pognębić } & \text { 'depress/trouble' } \\ \text { gniewać } & \text { pogniewać } & \text { 'anger' } \\ & \text { rozgniewać } & \text { 'anger' } \\ \text { martwić } & \text { zmartwić } & \text { 'worry' } \\ \text { nękać } & \text { znękać } & \text { 'bother, torment' } \\ \text { niepokoić } & \text { zaniepokoić } & \text { 'worry' } \\ \text { nudzić } & \text { znudzić } & \text { 'bore' } \\ \text { pasjonować } & \text { zapasjonować } & \text { 'fascinate' } \\ \text { peszyć } & \text { speszyć } & \text { 'abash' } \\ \text { razić } & \text { urazić } & \text { 'offend' } \\ \text { smucić } & \text { zasmucić } & \text { 'sadden' } \\ \text { straszyć } & \text { przestraszyć } & \text { 'frighten' } \\ & \text { nastraszyć } & \text { 'frighten' } \\ & \text { wystraszyć } & \text { 'frighten' } \\ \text { szokować } & \text { zastraszyć } & \text { 'frighten' } \\ \text { trapić } & \boldsymbol{z a s z o k o w a c ́ ~} & \text { 'startle, shock' } \\ \text { złościć } & \text { zszokować } & \text { 'startle, shock' } \\ & \text { strapić } & \text { 'bother, worry' } \\ & \text { zezłościć } & \text { 'anger, annoy' } \\ & \text { rozzłościć } & \text { 'anger, annoy' } \\ & & \\ & & \end{array}$

Class B: prefixed perfective verb, prefixed imperfective verb (SI)

$\begin{array}{lll}\text { perfective } & \text { imperfective } & \text { English equivalent } \\ \text { obrazić } & \text { obrażać } & \text { 'offend' } \\ \text { oburzyć } & \text { oburzać } & \text { 'outrage, shock' } \\ \text { olśnić } & \begin{array}{l}\text { olśniewać } \\ \text { onieśmielać }\end{array} & \text { 'dazzle, stun' } \\ \text { onieśmielić } & \text { 'intimidate, abash' } \\ \text { oszołomić } & \text { oszołamiać } & \text { 'overwhelm' } \\ \text { pocieszyć } & \text { pocieszać } & \text { 'console, comfort' } \\ \text { przejaćc } & \text { przejmować } & \text { 'distress' } \\ \text { przerazić } & \text { przerażać } & \text { 'horrify' } \\ \text { przytłoczyć } & \text { przytłaczać } & \text { 'horrify' } \\ \text { rozczulić } & \text { rozczulać } & \text { 'touch' } \\ \text { rozkochać } & \text { rozkochiwać } & \text { 'enamor' } \\ \text { rozrzewnić } & \text { rozrzewniać } & \text { 'move' } \\ \text { rozweselić } & \text { rozweselać } & \text { 'cheer up' } \\ \text { rozwścieczyć } & \text { rozwścieczać } & \text { 'infuriate' }\end{array}$




$\begin{array}{lll}\text { urzec } & \text { urzekać } & \text { 'bewitch, captivate' } \\ \text { wzruszyć } & \text { wzruszać } & \text { 'touch, move' } \\ \text { zachwycić } & \text { zachwycać } & \text { 'delight' } \\ \text { zawstydzić } & \text { zawstydzać } & \text { 'shame, embarrass' } \\ \text { zdumieć } & \text { zdumiewać } & \text { 'amaze' } \\ \text { zniechęcić } & \text { zniechęcać } & \text { 'dishearten' }\end{array}$

(20) $\operatorname{Exp}_{\mathrm{DAT}}-\mathrm{S}_{\mathrm{NOM}}$ (Exp in dative case, $\mathrm{S}$ in nominative case)

Class A: bare imperfective verb, prefixed perfective verb

$\begin{array}{lll}\text { imperfective } & \text { perfective } & \text { English equivalent } \\ \text { brzydnać } & \text { zbrzydnać } & \text { 'be fed up' } \\ & \text { obrzydnać } & \text { 'be fed up' } \\ \text { imponować } & \text { zaimponować } & \text { 'impress, dazzle' } \\ \text { podobać się } & \text { spodobać się } & \text { 'appeal to' } \\ \text { szkodzić } & \text { zaszkodzić } & \text { 'harm' }\end{array}$

Class B: prefixed perfective verb, prefixed imperfective verb (SI)

$\begin{array}{lll}\text { perfective } & \text { imperfective } & \begin{array}{l}\text { English equivalent } \\ \text { dokuczyć }\end{array} \\ \text { obrzydzić } & \begin{array}{l}\text { dokuczać } \\ \text { obrzydzać }\end{array} & \text { 'bother' } \\ \text { pochlebić } & \text { pochlebiać } & \text { 'flatter, adulate' } \\ \text { przeszkodzić } & \text { przeszkadzać } & \text { 'disturb' } \\ \text { schlebić } & \text { schlebiać } & \text { 'flatter' } \\ \text { ubliżyć } & \text { ublizać } & \text { 'insult' } \\ & & \\ \text { Exp }_{\text {Nom }} & & \\ \text { imperfective } & \text { perfective } & \text { English equivalent } \\ \text { smutnieć } & \text { posmutnieć } & \text { 'be sad, sadden' } \\ \text { weseleć } & \text { poweseleć } & \text { 'brighten up' }\end{array}$

As the examples given above demonstrate, most psych verbs have imperfective and perfective counterparts, although there are a few imperfectiva tantum psych verbs, e.g. bać się 'fear' in (17), which is at the same time an inherently reflexive verb. ${ }^{17}$ The imperfective verbs in (16) and (17) are stative, individual-level predicates expressing dispositions. The case of the object in (16) is structural, as evidenced by the obligatory realization of the direct object, which is in the accusative case in positive polarity contexts, with genitive case in negative polarity contexts, a phenomenon known as Genitive of Negation $(\mathrm{GoN})$. This is illustrated in (22b). GoN is categorical in Polish and it only affects structural accusative case, i.e. the case of a nominal complement of

${ }^{17}$ Inherently reflexive verbs do not have lexical entries lacking się, e.g. bać *(się) 'fear' modlić *(się) 'pray', śmiać ${ }^{i *}(s i e ̨)$ 'laugh', etc. A tentative analysis of the structure of lękać się 'fear' is shown in (i), where się is in the specifier of the verbalizer $-a$. The root $\sqrt{l e q k-\text { undergoes head-to-head }}$ movement to v. Agreement morphology attaches to the head lęka-. Notice that się is not present in the structure of a related adjective, e.g. lękliwy 'fearful'.

(i) $\left[_{\mathrm{V}}\right.$ się $\left.\left.\left[\mathrm{V}_{\mathrm{V}}-a\right][\sqrt{ } l e ̨ k-]\right]\right]$ 
a transitive verb (cf. Willim 1990). The verbs in this class have verbal passives (cf. Rozwadowska and Bondaruk 2019; Bondaruk 2020).

(22) a. Jan kochatl/ pokochat ${ }^{P}$ Marysięl ${ }^{\star}$ Marysi.

John loved po.loved Mary.ACC Mary.GEN

'John loved/started loving Mary'

b. Jan nie kochat'/ pokochat ${ }^{*}$ Marysię/ Marysi.

John not loved po.loved Mary.ACC Mary.GEN

'John did not love/start loving Mary'.

The $S$ argument of the imperfective nienawidzićl is in the genitive, unlike the $S$ argument of the perfective znienawidzić ' 'hate', which is in the accusative. However, as nienawidzićl can be passivized, the genitive case of the $S$ argument of the imperfective verb seems to be a variety of structural case, verbs assigning inherent case to their internal argument not being passivizable in Polish (cf., among others, Bondaruk 2020). The verbs listed in (16) have a prefix only in the perfective stem. The exception is podziwiac' ' 'admire', in which the combination of the prefix and the root $d z i w$ - 'wonder' is not compositional. The syntactic structure that I propose for the verbs with Exp in nominative case in (16) and (17), which adapts the insights into such structures in Ramchand (2008) and Cuervo (2015), is given in (23), where Exp is the specifier of VoiceP. ${ }^{18}$

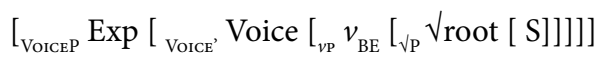

The verbs in (17) distribute in structures with $\operatorname{Exp}_{\mathrm{NOM}}$ and an oblique object $\left(\mathrm{S}_{\mathrm{OBL}}\right)$. The oblique object can be a PP, e.g. tęsknić I 'miss, yearn' c-selects $z a$ 'for'$\mathrm{PP}$ or do 'to'-PP, or an NP marked with lexical/inherent case, e.g. ufać ' 'trust' takes the $\mathrm{S}$ argument in the dative. ${ }^{19}$ Grammatical aspect does not affect the argument realization patterns of psych verbs in the classes illustrated in (16) and (17) except for the difference in case-marking of the $S$ argument of the perfective verb znienawidzić ${ }^{P}$ 'hate' compared with nienawidzićl 'hate'.

The verbs in (18) occur in reflexively-marked active Voice syntax, where sie alternates with a lexical $\operatorname{Exp}_{\mathrm{ACC}}$ of a related verb belonging to the class

${ }^{18}$ For reasons of space, I do not discuss the syntax of all structures with Polish psych verbs here. However, I assume that verbs are syntactically decomposed into a number of verbal layers on top of a category-neutral root and the external argument (EA) is severed from the verb (cf., among others, Alexiadou et al. 2015 and the references therein), as shown in (i), where $\mathrm{v}$ is the verbalizing suffix, which determines the inflectional class of the verb and is the locus of the event argument. As mentioned in Section 1, Asp is the locus of the null operators of perfective or imperfective aspect (Ramchand 2004, 2007; Tatevosov 2011, 2015). For clarity, I provide schematic representations of some selected constructions under discussion in the main text.

(i) $\left[_{\mathrm{TP}}\right.$ Tense $\left[{ }_{\text {Asp }}\right.$ Asp $\left[{ }_{\text {VorceP }}\right.$ EA [ ${ }_{\text {Voice }}$ Voice $\left.\left.\left.\left.\left[_{\mathrm{vP}}\left[\mathrm{v}\left[_{\text {RoorP }} V_{\text {root XP }}\right]\right]\right]\right]\right]\right]\right]$

${ }^{19}$ Following Dahl and Fedriani (2012), oblique objects are PP complements of a verb as well as NPs marked with idiosyncratic case or inherent, theta-related case. 
illustrated in (19). ${ }^{20}$ The ability of a psych verb/verbal root to occur with Exp in the accusative (cf. (23a)) or in the nominative in a reflexively-marked structure, in which się blocks a lexical $\operatorname{Exp}_{\mathrm{ACC}}$, correlates with a change in the linking of the arguments to the syntax.

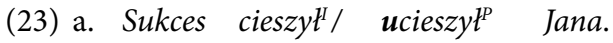
success delighted u.delighted John '(His/The) success delighted John.'

b. Jan cieszyt się/ucieszyt ${ }^{P}$ sięz sukcesu. John delighed SE u.delighted SE from success 'John was pleased about (his/the) success.'

Following Rozwadowska and Bondaruk (2019), here I will take the verbs occurring in the realization class in (18) to be unergative. The $S$ argument (T/SM in Rozwadowska and Bondaruk 2019) can be realized with a PP, as in (23b), or with an NP marked with instrumental case, depending on the verb. As argued by Rozwadowska and Bondaruk (2019), structures like (23b) are neither unaccusative nor anticausative, Polish not having a causative psych alternation, unlike e.g. Greek. ${ }^{21}$ In this approach, się is not a marker of valency reduction in the construction illustrated in (23b), as both the verbs in the unergative syntax in (18) and their related object experiencer verbs in (19) express a relation between Exp and S. Neither is the reflexive się an unaccusative marker, unlike $s i$ in reflexively-marked structures with preoccupare 'worry'-verbs in Italian (Belletti and Rizzi 1988, 2012). Taking the external argument of an unergative predicate to be introduced by a Voice head, I propose here that się occurring in the reflexively-marked construction in (18) is the vocabulary item realizing an active Voice head with antipassive properties. The Voice head is thematic and projects the external argument to the syntax, but it does not have the property of assigning accusative case, which is absorbed by sie, a vocabulary item that realizes it. Thus, $S$ is realized as an oblique object. In other words, a thematic active Voice head realized with an overt case-absorbing clitic (się) intransitivizes or detransitivizes a dyadic predicate morphosyntactically, as shown in (24). As a nominative subject in an unergative structure, Exp is agent-like (Dahl and Fedriani 2012; cf. also Rozwadowska and Bondaruk 2019). Many of the verbs with $\operatorname{Exp}_{\mathrm{NOM}}$ can be interpreted dynamically, the experiencing

${ }^{20}$ The only psych verb occurring in the reflexively-marked syntax that does not occur also in the $\operatorname{Exp}_{\mathrm{ACC}}-\mathrm{S}_{\mathrm{NOM}}$ syntax is the verb kochaćl 'love'. The difference between the transitive kochać and the morphosyntactically intransitive kochać się seems to lie in the former being an individual-level predicate expressing a disposition and the latter allowing reference to a transient emotional state of Exp.

${ }^{21}$ Fleischhauer (2013) analyzes German reflexive OE psych verbs as anticausatives. If this is correct, German licenses the psych causative alternation like Greek. 
individual perceptibly externalizing the internal emotional state in behavior, as illustrated in (25) (cf. also Fleischhauer 2013).

(24) $\left[_{\text {VoICEP }} \operatorname{Exp}\left[{ }_{\text {VoICE' }}\left[\left[_{\text {OOIC }}\right.\right.\right.\right.$ się $\left.\left.\left.\left[_{\mathrm{vp}} \mathrm{v}\left[{ }_{\sqrt{P}} \sqrt{ }[\mathrm{S}]\right]\right]\right]\right]\right]$

(25) $W$ trakcie rozmowy mężczyzna bardzo nerwowo

in duration conversation man very nervously

się zachowywatl, denerwowatl się. (Google)

SE behaved annoyed SE

'During the conversation, the man was behaving very nervously. He was annoyed.'

As observed by Rozwadowska and Bondaruk (2019), some of the verbs in the class illustrated in (18) allow the S argument to be omitted. The possibility of omitting the 'demoted'/oblique object also correlates with morphosyntactic intransitivization or detransitivization of a dyadic predicate in antipassive structures cross-linguistically (Polinsky 2017). The verbs that allow omission of the S argument include nudzićl się 'be bored', denerwowaćl się 'be annoyed', zakochać $c^{P}$ się 'start loving', rozweselić ${ }^{P}$ się 'cheer up', zaniepokoić ${ }^{P}$ się 'worry', etc. Grammatical aspect does not affect the possibility of omitting the $S$ argument, as shown in (25) above and in (26).

(26) Kierowca busa zdenerwowat ${ }^{p}$ sie podczas kontroli. (Google)

driver bus.GeN z.annoyed SE during inspection

'The bus driver got upset during the inspection.'

Most, but not all verbal roots listed in (18), i.e. the roots that can occur in the reflexively-marked unergative syntax (cf. (24)), can also occur in structures with an object experiencer in the accusative (cf. (19)). The exceptions are olśnićp/olśniewaćl 'dazzle', oszołomićc $P$ /oszołamiaćl 'overwhelm', and urzec ${ }^{P} /$ urzekaćl 'bewitch, captivate'. An analysis explaining this asymmetry is beyond the scope of this paper, but I tentatively suggest here that the reason why the above-mentioned verbs do not occur in the reflexively-marked unergative active Voice syntax is that the states of being dazzled, overwhelmed or bewitched seem to be out of human control, i.e. the experiencer argument is too patientlike to be an external argument introduced by an active Voice head. ${ }^{22,23}$

Unlike the verbal roots in the $\operatorname{Exp}_{\mathrm{ACC}}-\mathrm{S}_{\mathrm{NOM}}$ class (cf. (19)), the verbal roots in the $\operatorname{Exp}_{\mathrm{DAT}}-\mathrm{S}_{\mathrm{NOM}}$ class (cf. (20)) do not occur in the unergative reflexively-marked active syntax (cf. (24)). The argument in the dative case, which is

${ }^{22}$ The fact that not all verbs in the class in (19) can occur in the unergative syntax (cf. (24)) speaks against deriving the nominative Exp via movement in the syntax.

${ }^{23}$ The likely reason why there is no unergative imperfective verb straszyćt się with the meaning of 'fear, be frightened' is that Polish has two other imperfective verbs with $\operatorname{Exp}_{\mathrm{NOM}}$ lexicalizing the concept FEAR, the verb bać się I fear, be frightened', which is lexically reflexive and has no perfective partner, and the lexically reflexive verb lękać się I'fear', which has a perfective partner. These two verbs likely block $\operatorname{Exp}_{\mathrm{NOM}}$ verb ${ }^{\star}$ straszyć $c^{I}$ sie ' fear, be frightened'. 
non-structural case in Polish, is an external argument (EA) in the specifier of $\nu \mathrm{P}$, as suggested for Polish in Bondaruk (2020). Alternatively, it is an EA in the specifier of ApplP, as suggested for parallel structures in Greek in Alexiadou and Anagnostopoulou (2020). Being an external argument, $\operatorname{Exp}_{\mathrm{DAT}}$ cannot be merged in the specifier of active Voice in (24), as its argument status would not change and the structure would not have a different interpretation. At the same time, as the second argument of a verb in class (20), e.g. imponować $c^{I}$ 'impress, dazzle', can be inanimate, it could not be merged in the specifier of a reflexivley-marked active Voice, as the argument introduced by a reflexivelymarked Voice head is an agent or it is agent-like.

Apart from $\operatorname{Exp}_{A C C}-S_{N O M}$ verbs (cf. (19)), Polish also has $\operatorname{Exp}_{D A T}-S_{N O M}$ verbs (cf. (20)). Agentively or eventively interpreted verbs with Exp in the accusative and $\mathrm{S}$ in the nominative (cf. ((19)) are found in verbal passives. Thus, they behave like canonical transitive verbs, with Exp an external argument of Voice, unlike their Greek counterparts (cf. Alexiadou and Anagnostopulou 2020). Unambiguously stative verbs in (19) and (20) are argued to be internal arguments in a double ergative syntax in Bondaruk (2020). On this analysis, Exp is merged higher than S VP-internally and the surface $S>$ Exp order is derived by movement (cf. also Belletti \& Rizzi 1988, 2012; Dahl \& Fedriani 2012). The accusative case of the Exp argument of verbs in the class in (19) is structural, as it is subject to GoN. The imperfective and perfective verbs with the same lexical meaning in (19) and (20) do not differ with respect to argument structure and argument realization patterns. The verb/root straszyć ' 'frighten' listed in (19) can be perfectivized with three different prefixes, viz. prze-, na-, and $w y$-. There do not seem to be any semantic differences between the verbs derived with the prefixes, although nastraszy $\dot{c}^{p}$ tends to imply the presence of an agent argument. ${ }^{24}$ Also non-psych perfective verbs may have stems formed with different prefixes (cf. Laskowski 1999: 83; Szymanek 2010: 139), a phenomenon known as prefix doubles. For example, płowieć ' 'lose color' has two perfective stems: spłowiećc 'lose color' and wyptowieć ' 'lose color'. Importantly, the prefixes in prefix doubles are never lexical prefixes. In contrast to the prefixes prze-, na-, and $w y$-perfectivizing straszyćl 'frighten', the prefix $z a$ - derives $z a s t r a s z y c^{p}$ 'intimidate', which is an agentive verb.

${ }^{24}$ However, nastraszyć is also licensed in the absence of the agent, as shown in (i) below and (ii).

(i) ...zaczęła coś mruczeć, ... co go niemało ...started.3SG.F something mutter what he.ACC not.little nastraszyło ${ }^{P}$. (Google)

na.frightened.

'She started muttering something, ... which frightened him a lot.'

(ii) Stara nastraszyła ${ }^{P}$ się... (SJPC)

old.lady na.frightened sE

'The old woman felt frightened...' 
In addition, Polish has two psych verbs forming a class of their own, smutniećl/posmutniećc 'be sad, sadden' and weselećl $^{\prime} /$ poweseleć $^{p}$ 'cheer up, brighten up. The two verbs are monovalent unaccusatives. As shown in Cetnarowska (2000), perfective unaccusative verbs denoting change of state or location have resultative participles in $-l(y)$, in contrast to perfective intransitive unergatives in Polish. Both posmutniećc 'sadden' and poweseleć $c^{p}$ 'cheer up/brighten up' have resultative participles in $-l(y)$, viz. posmutniat $(y)$ and poweselat $(y)$ respectively, as shown in (27a) and (27b). Other intransitive verbs with participles in $-\ell(y)$ are all verbs of change of state or location, e.g. zgnit $(y)$ ' $r o t$ ', zwięd $(y)$ ' 'wilted', $\boldsymbol{w} y \operatorname{sch} t(y)$ 'dried up', $\boldsymbol{z}$ mart(y) 'dead', $\boldsymbol{p r z y b y t ( y )}$ 'arrived', etc. Intransitive unergative verbs do not have resultative participles, e.g. pobiegaćp 'run for a while' does not have a participle in $-\nmid(y)$, ${ }^{*}$ pobiegat $(y)$ 'po.run.PTCP(AGR)' being unavailable.

(27) a. W sukurs posmutniałemu in rescue po.saddened.sG.M.DAT

\section{[...] proboszczowi przyszli} rector.SG.M.DAT came jego wikariusze [...]. (Google)

his vicars

'The saddened rector's vicars came to his rescue.'

b. Szybko wyszedt $z$ sali, uciekając przed quickly left.3sG.m from room running before nagle poweselatym Feliciano. (Google) suddenly po.brightened.up.sG.M.INST Feliciano.sG.M.INST 'He quickly left the room, running away from Feliciano, who had suddenly cheered up.

Wrapping up, Polish psych verbs exhibit considerable morphosyntactic variability, similarly to psych verbs in other languages (cf. Belletti and Rizzi 1988, 2012; Pesetsky 1995; Landau 2010; Dahl and Fedriani 2012). Unlike the psych verbs in the early Indo-European languages investigated in Dahl and Fedriani (2012), which fall into five argument realization classes, Polish psych verbs fall into six argument realization classes: verbs with Exp as the only argument $\left(\operatorname{Exp}_{\mathrm{NOM}}\right)$, two classes with the first merge Exp $>\mathrm{S}$ order $\left(\operatorname{Exp}_{\mathrm{NOM}}>\mathrm{S}_{\mathrm{ACC}}\right.$ and $\operatorname{Exp}_{\text {NOM }}>\mathrm{S}_{\mathrm{OBL}}$ ), one class of verbs occurring in reflexively-marked unergative active voice syntax with Exp an external argument of Voice in the nominative, some of which allow omission of $S$, and two classes with $S>$ Exp order. However, only stative verbs with Exp in the accusative have derived surface $S>\operatorname{Exp}$ order in Polish. The Exp $>$ S order is not a derived order in structures with $\operatorname{Exp}_{\mathrm{ACC}}$ interpreted agentively or eventively. The isolated class of monovalent unaccusative verbs with $\operatorname{Exp}_{\mathrm{NOM}}$ is absent in Dahl and Fedriani's (2012) taxonomy. Furthermore, unlike modern Italian, which has two subclasses of dyadic psych verbs argued to be unaccusative in Belletti and Rizzi $(1988,2012)$ : dyadic unaccusative psych verbs in the preoccuparsi 'worry'-class and dyadic 
unaccusative predicates in the piacere 'like'-class, the verbs occurring in the Polish inverted $\operatorname{Exp}_{\mathrm{ACC}}>\mathrm{S}_{\mathrm{NOM}}$ construction are double ergatives and not unaccusatives (Bondaruk 2020). Except for the difference in the case-marking of the $S$ argument of nienawidzićl and znienawidzić ' hate', grammatical aspect does not affect case assignment and it does not affect c-selection. Imperfective and perfective Polish psych verbs do not differ in their core lexical meaning and their argument structure and argument realization patterns are not affected by grammatical aspect, except for the verbs in the class of verbs with $\operatorname{Exp}_{\mathrm{ACC}}$. Unlike unambiguously stative verbs in this class, whose Exp argument is VP-internal (Bondaruk 2020), ambiguous verbs in this class may map Exp onto an external argument depending on the event structure. I will return to the question of the relation between argument structure and event structure of Polish psych verbs in the next section.

The perfective stems of psych verbs as a class are formed with the prefixes na-; o/ob-; po-; pod-; prze-, roz(e)-; u-; wy-; wz-; $z(e) / s-$ and $z a-$, which do not exhibit any clear preferences for distributing in verbs with a particular argument realization option. For example, even $z a$-, which is the most frequent prefix forming perfective stems of Polish psych verbs, does not derive the verbs in (16), verbs in class B in (20), and verbs in (21). The 11 prefixes deriving perfective psych verbs constitute a vast majority of prefixes analyzed as pure perfectivizers in Łaziński (2020: 75), which are presented in the order of frequency in (28). ${ }^{25}$

(28) Polish pure perfectivizers (Łaziński 2020: 75):

$z(e) / s-/ s_{-}^{-} ; z a-;$ wy-; po-; u-; o/ob-; na-; prze-; roz(e)-; w-; od-; przy-; pod-.

Given that a vast majority of perfective Polish psych verbs do not differ in their (core) lexical meaning, argument structure and argument realization patterns from their imperfective counterparts, the prefixes in Polish perfective psych verbs are not argument structure modifiers. At the same time, there are perfective psych verbs with SI partners, as illustrated with class B verbs in (18), (19) and (20). In addition, in some perfective psych verbs the contribution of the prefix to the root cannot be interpreted in a (fully) compositional way. Examples include the object experiencer verb zaskoczyć 'surprise', in which $z a$ combines with the base verb skoczyć 'jump. ${ }^{26}$ In pocieszyćp 'console', the base verb/root is cieszyćl 'please'. In yet other cases, e.g. zadowolić $^{P}$ and $z$ dumieć ${ }^{P}$, the prefix is isolable only on historical grounds (cf. Boryś 2008). From the synchronic point of view, it may be best analyzed as attached directly to bound

${ }^{25}$ Omitted in (28) are two prefixes, $d o$ - and $w z$-, which are not treated as aspectual in both of the corpus-based dictionaries of Polish on which Łaziński's (2020) study is based.

${ }^{26}$ Already in Old Polish, the verb zaskoczyci ${ }^{p}$ 'surprise' denoted a (psychological) reaction to a sudden and by metaphorical extension, unexpected event (cf. Janowska and Pastuchowa 2005: 190). 
roots, as there are no free roots ${ }^{*}$ dowolić and ${ }^{*}$ dumieć in contemporary Polish. Alternatively, these prefix + root combinations are lexicalized. Thus, classifying the prefixes forming perfective stems of psych verbs as superlexical, merged in AspP (Ramchand 2004, 2007), is problematic (cf. also Žaucer 2005, Wiland 2012 and Tatevosov 2015 in reference to the inceptive $z a$ - in Slovenian, Polish and Russian respectively). What is noteworthy is that while the transition into an activity or non-psych state is encoded with a single inceptive prefix $z a-$, as in $z a p l a k a c^{P}$ 'start crying' and zamieszkać ${ }^{P}$ 'start living, come to live', the transition into a psych state is encoded with as many as 11 distinct prefixes. If psych verbs are to be treated as a lexical class, the perfective counterparts differing from the (secondary) imperfective ones only in having a constant component of the onset to a given state, the perfective stems should have a uniform morphosyntactic analysis. I suggest here that although the prefixes in perfective psych verbs in Polish are not argument structure modifiers, they are not merged outside VP (cf. also Žaucer 2005 and Tatevosov 2011, 2015).

\subsection{Interim summary and outlook}

In this section, the 11 prefixes forming perfective psych predicates in Polish have been shown not to change the core meaning of the base verbs or roots they combine with and thus not to be argument structure modifiers. This is true regardless the argument realization class of a psych verb. The distribution of the prefixes deriving the verbs in a given class is not predicted by the argument realization class. In Sections 3 and 4, to appear in Part 2 of this paper in volume 16(1) of this journal, I will focus on the internal temporal structure of perfective psych verbs, which can denote a punctual transition into a state, similarly to non-culminating achievements (happenings), or an event of gradual scalar change. I will argue that perfective psych verbs are verbs of scalar change in all their uses and that the different readings reflect a difference in the mereological complexity of a scale along which their event stages are ordered. A two-point scale associated with a psych verb gives rise to a punctual event of change. A multivalued scale gives rise to a gradual scalar change reading. Whether the event denoted by a perfective psych verb is punctual or scalar change is extended in time, the verb has in its semantic representation a scalar degree that maps onto a single time moment which is the beginning of a given psych state. 


\section{References}

Alexiadou Artemis, Anagnostopoulou Elena, Schäfer Florian (2015). External Arguments in Transitivity Alternations. A Layering Approach. Oxford: Oxford University Press.

Alexiadou Artemis, Anagnostopoulou Elena (2020). Expriencers and causation. In Perspectives on Causation, Elitzur A. BAR-Asher Siegal, Nora Boneh (eds.), 297317. Cham, Switzerland: Springer Nature Switzerland AG 2020.

Arad Maya (1998). Psych-notes. UCL Working Papers in Linguistics 10, 203-223.

BACH Emon (1986). The algebra of events. Linguistics and Philosophy 9, 5-16.

BEAvers John (2012). Lexical aspect and multiple incremental themes. In Telicity, Change, and State: A Cross-categorial View of Event Structure, Violeta Demonte, Louise McNally (eds.), 23-59. Oxford: Oxford University Press.

BEAVERs John (2013). Aspectual classes and scales of change. Linguistics 54, 681-706.

Belletti Adriana, Rizzi Luigi (1988). Psych-verbs and theta theory. Natural Language and Linguistic Theory 6, 291-352.

Belletti Adriana, Rizzi Luigi (2012). Moving verbal chunks in the low functional field. In Functional Heads: The Cartography of Syntactic Structures, Vol. 7, Laura BRUGÉ, Anna Cardinaletti, Giuliana Giusti, Nicola Munaro, Cecilia Poletto (eds.), 129-137. Oxford: Oxford University Press.

BiaŁy Adam (2005). Polish Psychological Verbs at the Lexicon-Syntax Interface in Cross-linguistic Perspective. Frankfurt am Main: Peter Lang.

BondARUK Anna (2020). The syntax of accusative and dative experiencers in Polish. In RozWADOWSKA, BoNDARUK (eds.), 141-212.

Bondaruk Anna, Szymanek Bogdan (2007). Polish nominativeless constructions with dative experiencers: Form, meaning and structure. Studies in Polish Linguistics 4, 61-99.

Boryś Wiesław (2008). Słownik etymologiczny języka polskiego [An Etymological Dictionary of Polish]. Warszawa: Wydawnictwo Literackie.

Centnarowska Bożena (2000). The unergative/unaccusative distinction in Polish. In Proceedings of GLiP-1, Piotr BAŃski, Adam PrZEPIóRKowski (eds.), 35-46. Warszawa: IPI PAN.

Czaykowska-Higgins Ewa (1998). Verbalizing suffixes and the structure of the Polish verb. Yearbook of Morphology 1997, 25-58.

Cuervo Christina (2015). Causation without a cause. Syntax 18(4), 388-424.

DAHL Eystein, FEDRIANi Chiara (2012). The argument structure of experience: Experiential constructions in Early Vedic, Homeric Greek and Early Latin. Transactions of the Philological Society 110(3), 342-362.

Filip Hana (2003). Prefixes and the delimitation of events. Journal of Slavic Linguistics $11,55-101$.

FILIP Hana (2008). Events and maximalization: The case of telicity and perfectivity. In Theoretical and Crosslinguistic Approaches to the Semantics of Aspect, Susan Rothstein (ed.), 217-256. Amsterdam: John Benjamins Publishing Company.

FILIP Hana (2017). The semantics of perfectivity. Italian Journal of Linguistics 29(1), $167-200$. 
Filip Hana, Rothstein Susan (2006). Telicity as a semantic parameter. In Formal Approaches to Slavic Linguistics 14, James Lavine, Steven Franks, Hana Filip, Mila Tasseva-Kurktchieva (eds.), 139-156. Ann Arbor, MI: University of Michigan Slavic Publications.

FleischHauer Jens (2013). Degree Gradation of Verbs. Düsseldorf: Düsseldorf University Press.

GeHrke Berit (2008). Ps in Motion: On the Semantics and Syntax of P Elements and Motion Events. Utrecht: Utrecht University LOT Dissertation Series.

Gehrke Berit, Grillo Nino (2009). How to become passive. In Explorations of Phase Theory: Features, Arguments, and Interpretation at the Interfaces, Kleanthes K. Grohmann (ed.), 231-268. Berlin: de Gruyter.

Grafmiller Jason (2013). The semantics of syntactic choice. An analysis of English emotion verbs. Stanford, CA: Stanford University. $\mathrm{PhD}$ dissertation.

GrzegorCzykowa Renata, Laskowski Roman, WróBel Henryk (eds.) (1999). Gramatyka współczesnego języka polskiego. Morfologia [A Grammar of Contemporary Polish. Morphology].Warszawa: Wydawnictwo Naukowe PWN.

JanowsKa Aleksandra, PAstuchowa Magdalena (2005). Słowotwórstwo czasowników staropolskich: Stan i tendencje rozwojowe [Word-formation morphology of Old Polish verbs: State of the art and developmental tendencies]. Kraków: Universitas.

Kagan Olga (2015). Scalarity in the Verbal Domain. The Case of Verbal Prefixation in Russian. Cambridge: Cambridge University Press.

Kennedy Christopher, McNally Louise (2005). Scale structure, degree modification, and the semantics of gradable predicates. Language 81, 345-381.

KRIFKA Manfred (1989). Nominal reference, temporal constitution and quantification in event semantics. In Semantics and Contextual Expression, Renate BARTSCH, Johan van Benthem, Peter von Emde BoAs (eds.), 75-115. Dordrecht: Foris.

LANDAU Idan (2010). The Locative Syntax of Experiencers. Cambridge, MA: MIT Press.

LAskowski Roman (1999). Czasownik [Verb]. In GrzegorCzyKowA, LAsKowski, WRóBEL (eds.), 225-269.

Levin Beth (1993). English Verb Classes and Alternations. Chicago: The University of Chicago Press.

ŁAZIŃsKi Marek (2020). Wykłady o aspekcie polskiego czasownika [Lectures on Polish Verbal Aspect]. Warszawa: Wydawnictwa Uniwersytetu Warszawskiego.

ŁAzORCZy K Agnieszka (2010). Decomposing Slavic aspect: The role of aspectual morphology in Polish and other Slavic languages. Los Angeles: University of Southern California. PhD dissertation.

MŁynarczyk Anna (2004). Aspectual Pairing in Polish. Utrecht: Utrecht University LOT Dissertation Series.

Pastuchowa Magdalena, Stawnicka Jadwiga (2008). Czasowniki inicjalne w języku polskim - staropolszczyzna i współczesność [Initial Verbs in Polish - Old and Modern Polish]. In Słowo i tekst. Vol. 1: Funkcjonowanie języka [Word and text. Vol. 1: The Functions of Language], Piotr Czerwiński, Jadwiga Stawnicka (eds.), 27-42. Katowice: Wydawnictwo Uniwersytetu Śląskiego.

Pesetsky David (1995). Zero Syntax: Experiencers and Cascades. Cambridge, MA: The MIT Press. 
PiÑón Christopher (2001). A problem of aspectual composition in Polish. In Current Issues in Formal Slavic Linguistics, Gerhild Zybatow, Uwe Junghanns, Grit Mehlhorn, Luka Szucsich (eds.), 397-414. Frankfurt am Main: Peter Lang.

Polinsky Maria (2017) Antipassive. In Oxford Handbook of Egrativity, Jessica Coon, Diane Massam, Lisa Travis (eds.), 308-331. Oxford: Oxford University Press.

Przepiórkowski Adam, Bańko Mirosław, Górski Rafał, Lewandowska-Tomaszczyk Barbara (eds.) (2010). Narodowy Korpus Języka Polskiego. Warszawa: Wydawnictwo Naukowe PWN. http://www.nkjp.pl. Accessed May 1, 2020.

Ramchand Gillian C. (2004). Time and the event. The semantics of Russian prefixes. Nordlyd 32 (2), 23-361.

RAMCHAND Gillian C. (2007). Perfectivity as aspectual definiteness: Time and the event in Russian. Lingua 118(11), 1690-1715.

Ramchand Gillian C. (2008). Verb Meaning and the Lexicon. A First Phase Syntax. Cambridge: Cambridge University Press

RAPPAPORT Hovav Malka (2008). Lexicalized meaning and the internal temporal structure of events. In Crosslinguistic and Theoretical Approaches to the Semantics of Aspect, Susan Rothstein (ed.), 13-42. Amsterdam: John Benjamins.

RAPPAPORT Hovav Malka (2014). Building scalar changes. In The Syntax of Roots and the Roots of Syntax, Artemis Alexiadou, Hagit Borer, Florian Schäfer (eds.), 259-271. Oxford: Oxford University Press.

Rothmayr Antonia (2009). The Structure of Stative Verbs. Amsterdam: John Benjamins.

Rothstein Susan (2004). Structuring of Events: A Study in the Semantics of Lexical Aspect. Oxford: Blackwell Publishing.

Rothstein Susan (2020). Perfective is a V operator in Slavic, though not in English. In Current Developments in Slavic Linguistics. Twenty Years After, Teodora RADEvA-Bork, Peter Kosta (eds.), 155-172. Berlin: Peter Lang International Academic Publishers.

RozWADOWsKa Bożena (2003). Initial boundary and telicity in the semantics of perfectivity. In Investigations into Formal Slavic Linguistics, Peter Kosta, Joanna B£AszCzAK, Jens Frasek, Ljudmila GeIst, Marzena Żygis (eds.), 859-872. Frankfurt am Main: Peter Lang.

Rozwadowska Bożena (2012). On the onset of psych eventualities. In Sound Structure and Sense, Eugeniusz Cyran, Henryk Kardela, Bogdan SzymaneK (eds.), 533554. Lublin: Wydawnictwo KUL.

RozWADOWSKA Bożena (2020). Polish psych verbs as non-achievements. In RozWADOwsKA, BONDARUK (eds.), 23-74.

Rozwadowska Bożena, Bondaruk Anna (2019). Against the psych causative alternation in Polish. Studies in Polish Linguistics, Special Volume 1, 77-79.

RozWADowska Bożena, Bondaruk Anna (eds.) (2020). Beyond Emotions in Language. Psych Verbs at the Interfaces. Amsterdam/Philadelphia: John Benjamins Publishing Company.

SAloni Zygmunt, Woliński Marcin, WoŁosz Robert, Gruszczyński Włodzimierz, Skowrońska Danuta (2015). Słownik gramatyczny języka polskiego. Wyd. III [A Grammatical Dictionary of Polish, $3^{\text {rd }}$ edition]. http://sgjp.pl. Accessed June 10, 2020. Smith Carlota S. (1997). The Parameter of Aspect. Dordrecht: Kluwer Academic Publishers. Svenonius Peter (2004). Slavic prefixes inside and outside VP. Nordlyd 32(2), 205-253. 
Szymanek Bogdan (2010). A Panorama of Polish Word-Formation. Lublin: Wydawnictwo KUL.

TATEvosov Sergei (2011). Severing perfectivity from the verb. Scando-Slavica 57, 216-244.

TATEvosov Sergei (2015). Severing imperfectivity from the verb. In Formal Description of Slavic Languages: Proceedings of FDSL 10, Leipzig 2013, Gerhild Zyватоw, Petr BiskuP, Marcel Guhl, Claudia Hurtig, Olav Mueller-Reichau, Maria Yastrebova (eds.), 465-494. Frankfurt am Main: Peter Lang.

Vendler Zeno (1967). Linguistics in Philosophy. Ithaca: Cornell University Press.

Verhoeven Elisabeth (2007). Experiential Constructions in Yucatec Maya: A Typologically Based Analysis of a Functional Domain in a Mayan language. Amsterdam: John Benjamins.

Voorst Jan van (1992). The aspectual semantics of psychological verbs. Linguistics and Philosophy 15, 65-92.

WiEMER Björn, SERžAnt Ilja A. (2017). Diachrony and typology of Slavic aspect: What does morphology tell us? In Unity and Diversity in Grammaticalization Scenarios (Studies in Diversity Linguistics 16), Walter BISAng, Andrej Malchukov (eds.), 239307. Berlin: Language Science Press.

Wiland Bartosz (2012). Prefix stacking, syncretism, and the syntactic hierarchy. In Slavic Languages in Formal Grammar. Proceedings of FDSL 8.5, Brno 2010, Marketa ZIKovÁ, Mojmir DočEKal (eds.), 307-324. Frankfurt am Main: Peter Lang.

Willim Ewa (1990). On case-marking in Polish. Papers and Studies in Contrastive Linguistics 25, 203-220.

Willim Ewa (2006). Event, Individuation and Countability. Kraków: Wydawnictwo Uniwersytetu Jagiellońskiego.

Wróbel Henryk (1999). Czasownik [Verb]. In Grzegorczykowa, Laskowski, WRóbEL (eds.), 536-584.

ŽAUCER Rok (2005). Slovenian inceptive prefix $z a$-: a VP-internal P. In Proceedings of the 2005 Annual Conference of the Canadian Linguistic Association, Claire GURSKI (ed.), 1-12.

Ewa Willim

Jagiellonian University

Institute of English Studies

Al. Mickiewicza 9A, 31-120 Kraków

ewa.willim(at)uj.edu.pl 